\title{
Enam Alasan Guru Menggunakan Metode Ceramah pada Mata Pelajaran PAI
}

Tri Sumarsih ${ }^{1}$, Wirdati ${ }^{2}$

trisumamarsih98@gmail.com¹, wirdati@fis.unp.ac.id ${ }^{2}$ Universitas Negeri Padang ${ }^{1,2}$

\begin{tabular}{l}
\hline ARTICLE INFO \\
\hline Article history: \\
Received, 07 Februari \\
2022 \\
Revised, 16 Februari \\
2022 \\
Accepted, 28 Februari \\
2022 \\
\hline Keywords: \\
Pendidikan Agama Islam, \\
Era Globalisasi, Metode \\
Ceramah
\end{tabular}

Clonflict of Interest:

None

Funding:

None

\begin{abstract}
Curriculum 13 requires the use of student-based methods. However, at SD Negeri 161/II Bukit Sari, it turns out that teachers tend to continue to use the lecture method. This study aims to determine the reason PAI teachers still use the lecture method, as one of the general methods in learning. The research method used is qualitative with a case study approach. To obtain data in the field which aims to describe and answer the problems being studied, and in the research process, the authors need to use data collection methods, namely the observation method by observation and the interview method consisting of Islamic religious education teachers, school principals, homerooms and students. To strengthen research data, researchers also take data through documentation. All interview data were analyzed by collecting data, reducing data, presenting data, and ending with the conclusion. The data validation technique was carried out by researchers using source triangulation, which was done by checking the data that had been obtained through several sources. The results of this study indicate that there are 6 reasons teachers still use the lecture method: First, the method used in schools is the lecture method combined with discussion, question and answer methods, and assignments. Second, this lecture method is an effective and easy method to apply. Third, the condition of the class during the learning process is conducive. Fourth, the facilities provided at the school are adequate, but if the student-based method is applied, it cannot run well because the media and other aids are not sufficient. Fifth, while using the lecture method students feel happy and easy to understand the material. Sixth, students' behavior and responses during the learning process are good.
\end{abstract}

Corresponding Author: Tri Sumarsih, Department Islamic Education Faculty of Social Science Universitas Negeri Padang, Indonesia, Email: trisumamarsih98@gmail.com Phone No.: +6281314363976 


\section{Pendahuluan}

Di era globalisasi dan Revolusi Industri 4.0 menuntut adanya sumber daya manusia yang berkualitas tinggi. Kualitas sumber daya manusia ini hanya diperoleh dari proses belajar atau pendidikan. Pendidikan sangatlah penting dalam kehidupan manusia, maka setiap manusia berhak mendapatkan pendidikan. Pendidikan adalah proses belajar mengajar untuk membimbing peserta didik agar meningkatkan pengetahuan melalui beberapa pengalaman belajar sesuai dengan bidang dan pengetahuananya, sehingga peserta didik mempunyai sifat unggul dalam bersosialisasi dengan masyarakat sebagai wujud pengabdian dan pengetahuan untuk dirinya (Sagala, 2013:43). Proses pendidikan dan pembelajaran memerlukan metode yang sistematis guna membuat peserta didik menjadi lebih aktif dalam mengikuti kegiatan belajar di kelas. Metode pembelajaran adalah media tranformasi dalam pembelajaran agar kompetensi yang diinginkan selama proses pembelajaran tercapai (Maisaroh, 2013:167).

Seiring perkembangan zaman dan berkembangnya teknologi, seharusnya lebih berkembang pula penggunaan metode pembelajaran, terlebih dengan suatu lembaga pendidikan yang sudah menerapkan pembelajaran Kurikulum 13. Kurikulum 13 merupakan kurikulum terbaru di Indonesia yang ditetapkan pada tahun 2013 dan direvisi pada tahun 2016-2018. Kurikulum 13 ini lebih menekankan kepada 3 aspek yaitu menjadikan peserta didik berakhlak mulia (afektif), keterampilan (psikomotorik), serta pengetahuan (kognitif) yang berkesinambungan. Dengan ini diharapkan agar siswa lebih kreatif, inovatif dan produktif (Yusuf, 2018:267).

Dalam Kurikulum 13 sebagaimana yang terdapat dalam PP No. 103 Tahun 2014 banyak metode yang bisa digunakan atau diterapkan selama proses pembelajaran, di antaranya adalah presentasi, demonstrasi, drill and practice (latihan terus menerus dan praktif), diskusi, project based learning (pembelajaran berbasis proyek), problem based learning (pembelajaran berbasis masalah), diccovery learning (pembelajaran berbasis penemuan), dan lainnya. Metode-metode di atas diharapkan lebih banyak digunakan agar siswa menjadi lebih aktif dan kreatif. Akan tetapi pada kenyataannya SD Negeri 161/II Bukit Sari proses belajar pendidikan agama Islam masih banyak menggunakan metode ceramah. Metode ceramah adalah penyampaian materi pembelajaran dengan cara guru menerangkan dan siswa mendengarkan (Suprihatiningsih, 2016:34). Selama pembelajaran berlangsung guru menginginkan proses belajar berjalan dengan baik dan siswa mampu memahami materi yang dijelaskan oleh guru. Maka dari itu, seharusnya dalam penggunaan metode ceramah proses pembelajaran diselingi dengan metode lainnya. Menurut Rusiadi (2020:10) penggunaan metode pembelajaran yang divariasi, disinyalir dapat membantu pencapaian tujuan pembelajaran karena dalam proses pembelajaran siswa masih cenderung pasif maka dari itu diperlukannya variasi metode agar guru dapat menyampaikan materi secara optimal.

Berdasarkan observasi awal penulis di SD Negeri 161/II Bukit Sari, Kec. Jujuhan Ilir, Kab. Bungo Prov. Jambi, pada tanggal 30 April 2021 ditemukan bahwa guru masih menggunakan metode ceramah dalam proses pembelajaran. Penulis melihat bahwa penggunaan metode ceramah dilakukan hampir pada setiap proses pembelajaran. Sedangkan pada era globalisasi guru dituntut untuk menggunakan variasi metode yang 
Tri Sumarsih dan Wirdati: Enam Alasan Guru Menggunakan Metode Ceramah...

sesuai dengan perkembangan teknologi saat ini. Melihat kenyataan di atas, tentu ada suatu alasan yang melatarbelakangi penggunaan metode ceramah di SD Negeri 161/II Bukit Sari ini.

\section{Tinjauan Pustaka}

Pendidikan agama Islam adalah suatu mata pelajaran untuk membimbing peserta didik agar kelak menjadi seseorang yang dapat memahami agama Islam secara baik dan benar serta dapat memahami dan menghayati makna untuk mencapai suatu maksud dan tujuan agar kelak dapat mengamalkan dan menjadikan pedoman ajaran agama Islam sebagai pedoman hidupnya, dan dapat memberi keselamatan dunia dan akhirat (Samrin, 2015:105-106).

Tujuan pendidikan agama Islam menurut Peraturan Pemerintah Republik Indonesia (PPRI) No. 32 Tahun 2013 adalah untuk membentuk peserta didik menjadi manusia yang beriman dan bertaqwa kepada Tuhan Yang Maha Esa serta berakhlak mulia dan budi pekerti.

Menurut (Asfiati, 2020 :54-55) ruang lingkup pendidikan agama Islam sebagai berikut :

1) Alquran, materi ini diberikan dengan pembahasan tentang pengertian Alquran, Alquran ini sebagai pedoman umat muslim dan dapat membimbing kejalan yang lurus.

2) Hadist, hadist ini segala seatu yang bersumber dari nabi baik itu berupa perkataan, perbuatan, taqrir maupun sifatnya.

3) Fiqih, peseta didik diajarkan untuk memahami fiqih secara benar agar mempunyai pandangan yang lurus tentang fiqih.

4) Aqidah Akhlak, materi akidah akhlak mencakup keyakinan kepada Allah dengan memahami nama-nama dan sifat-sifat-Nya, keyakinan terhadap malaikat roh setan dan makhluk gaib lainya, serta kitab-kitab yang suci.

5) Sejarah Kebudayaan Islam, peserta didik diajarkan untuk mempelajari sejarah. Sejarah ini dijadikan gambaran dalam bertindak dan melakukan sesuatu.

Pembelajaran PAI dilaksankan sesuai dengan keadaan siswa dan kondisi lingkungan social masyarakat. Maka dari itu, era globalisasi ditandai dengan perkembangan teknologi yang sangat canggih, dengan kecanggihan teknologi yang beragam mampu memudahkan manusia untuk mendapatkan suatu informasi dari sudut wilayah dan dapat bekomunikasi dengan baik tanpa adanya pertemuan secara langsung (Nuriyati \& Chanifudin, 2020). Era globalisasi adalah perubahan zaman yang semakin modern serta meningkatnya ilmu, pengetahuan dan teknologi untuk mencapai perkembangan kehidupan manusia dengan adanya komunikasi dan transportasi yang menjadikan mereka fokus akan perkembangan teknologi (Janurharyono, 2019). Jadi era globalisasi dapat diartikan perkembangan zaman yang ditandai dengan perkembangan ilmu pengetahuan dan teknologi yang sangat mempengaruhi perubahan aspek manusia. Maka dari itu di era globalisasi ini lembaga pendidikan perlu adanya perubahan kurikulum di sekolah untuk penyesuaian dan antisipasi perubahan zaman.

Sesuai dengan kurikulum mutakhir yang diterapkan di indonesia, K-13 disyaratkan penggunaan metode yang lebih menekankan keaktifan siswa. Menurut bahasa, metode berasal dari bahasa Yunani, yaitu meta (sepanjang), hedos (jalan). Jadi, metode adalah cara kerja yang mempunyai sistem untuk memudahkan pelaksanaan terhadap suatu 
kegiatan guna untuk mencapai tujuan yang telah ditentukan (Fitrah, 2017 :36). Metode ceramah adalah seorang guru dalam mengajarkan materi pembelajaran kepada peserta didik dengan cara menyampaikan materi secara lisan dimana guru atau pengajar bersifat aktif sedangkan peserta didik bersifat pasif (Hanafi dkk, 2018:212213).

Metode ceramah memiliki beberapa langkah yaitu:

1) Langkah pembukaan yang terdiri dari: a) menjelaskan tujuan yang ingin dicapai. b) menentukan pokok-pokok materi yang akan dipelajari. c) mempersiapkan alat bantu. d) guru harus mengetahui bahwa siswa memahami tujuan pembelajaran yang akan dicapai. e) melakukan langkah apersepsi yaitu proses yang terjadi antara seusatu yang telah berlalu dengan sesuatu yang baru seperti halnya dalam pembelajaran guru meninjau kembali sampai mana pemahaman siswa tentang materi yang dipelajari sebelumnya dengan cara guru memberi pertanyaan kepada siswa

2) Kegiatan inti yang terdiri dari: a) menjaga kontak mata dengan siswa. b) menggunakan bahasa yang mudah dipahami oleh siswa. c) mempelajari materi pembelajaran yang sistematis, berurutan dan tidak melompat-lompat agar siswa mudah memahaminya. d) apabila ada respon dari siswa maka guru harus menanggapi. e) menjaga kelas agar selalu kondusif.

3) Langkah penutup yang terdiri dari: a) menyimpulkan materi yang telah dipelajari. b) merangsang siswa agar menanggapi atau memberi ulasan tentang materi pembelajaran yang telah dipelajari. c) mengevaluasi untuk mengetahui seberapa besar pemahaman siswa tentang materi yang dipelajari tersebut (Sanjaya.2016:149-151).

Selain itu metode ceramah juga memiliki kelebihan dan kekurangan di antaranya menurut Delita (2020: 169 kelebihan metode ceramah yaitu metode bisa digunakan untuk jumlah murid yang banyak, metode ini guru lebih menguasai kelas sehingga guru bias mengawasi siswa selama proses pembelajaran berlangsung, guru mudah menerangkan pembelajaran dengan baik, dan selama proses persiapan dan pelaksanaan pembelajaran tidak memerlukan waktu yang lama. Sedangkan menurut mudlofir \& Rusydiyah (2017:107) kelebihan metode ceramah yaitu guru dapat menguasai kelas, karena kelas tersebut merupakan tanggung jawab guru selama proses belajar berlangsung. Guru juga dengan mudah menerangkan materi pelajaran yang berjumlah banyak, karena guru dapat mengambil materi-materi pokok pembahasan saja, selama proses belajar dapat diikuti oleh peserta didik yang jumlahnya besar, mudah diterapkan karena metode ini hanya mengandalkan suara dan penjelasan dari guru serta tidak memerlukan alat peraga, dan ceramah tidak memerlukan setting kelas dan persiapan-persiapan yang rumit.

Kekurangan metode ceramah menurut Sanjaya (2016:148-149) yaitu materi yang dikuasai siswa sangat kurang karena dalam metode ini guru lebih aktif dari pada siswanya. Jika guru kurang memiliki kemampuan berbicara atau kurang menguasai kelas selama proses pembelajaran berlangsung maka metode ceramah ini sering dianggap metode yang membosankan. Metode ini sulit digunakan untuk mengetahui apakah siswa sudah memahami materi yang telah dipelajari. Setiap peserta didik memiliki kemampuan yang tidak sama dalam menangkap materi pembelajaran melalui pendengaran, dalam metode ini guru hanya menjelaskan verbalnya sedangkan siswa hanya mengandalkan audiotifnya. 
Tri Sumarsih dan Wirdati: Enam Alasan Guru Menggunakan Metode Ceramah...

\section{Metode}

Metode yang digunakan dalam penelitian ini adalah penelitian kualitatif dengan pendekatan study kasus (case study). Informan dalam penelitian ini adalah guru PAI, kepala sekolah, wali kelas dan siswa di SD Negeri 161/II Bukit Sari. Pengumpulan data dalam penelitian ini menggunakan teknik observasi dan wawancara, denagan informan guru PAI, kepala sekolah, wali kelas dan siswa. Ketetapan dan kebenaran data yang sudah berhasil digali, dikumpulkan dan dicatat dalam kegiatan penelitian serta harus dipastikan dengan baik. Untuk menguji kredibilitas dan pengecekan data, maka diperlukan teknik pengabsahan data dengan peneliti menggunakan triangulasi sumber yakni dilakukan dengan cara mengecek data yang telah diperoleh melalui beberapa sumber.

\section{Hasil dan Pembahasan}

Selalu ada alasan kenapa seseorang melakukan sesuatu terutama dalam melakukan hal-hal yang ada kaitanyanya dengan suatu proses pembelajaran. Ketika guru melakukan pembelajaran menggunakan metode ceramah pasti terdapat alasan dibalik semua itu. Pelaksanaan pembelajaran PAI di SD Negeri 161/II Bukit Sari hampir selalu menggunakan metode ceramah.

Untuk mengetahui alasan guru PAI masih menggunakan metode ceramah padahal di K13 dituntut untuk menggunakan metode pembelajaran yang berpusat pada siswa penulis sudah melakukan wawancara denan guru PAI di SD Negeri 161/II Bukit Sari. Hasil wawancara dengan Bu Suprapti S.Pd.I (wawancara 09 November 2021) adalah:

"Selama proses belajar saya menggunakan metode ceramah, tanya jawab, diskusi, dan penugasan. Saya tidak hanya menggunakan metode ceramah saja akan tetapi terkadang ibu selingi dengan metedo diskusi, metode ceramah ini saya terapkan untuk materimateri pokok saja. Metode ceramah ini metode yang sangat efektif dan mudah untuk diterapkakan, selain itu selama belajar menggnakan metode ceramah siswa juga merasa senang. Dalam penggunaan metode inovatif saya belom pernah menggunakannya karena fasilitas yang tersedia kurang memadai seperti media proyektor, computer dan lainya... Jadi metode ceramahlah yang efektif untuk diterapkan dan dikombinasikan menggunakan metode lainya".

Kemudian penulis juga mewawancarai wali kelas yang bernama ibu Martini S.Pd (wawancara tanggal 17 November 2021) mengatakan bahwa:

"Metode yang biasa digunakan dalam proses pembelajaran yaitu metode ceramah, diskusi, tanya jawab dan penugasan, dari beberapa metode ibu yang paling sering ibu gunakan yaitu metode ceramah. Metode ceramh ini metode yang sangat efektif untuk diterapkan, dan ibu juga bisa mengkondisikan suasana kelas dengan baik saat belajar... Suasana kelas saat proses belajar berlangsung sangat kondusif dan respon siswa baik terhadap materi yang saya ajarkan. Kondisi ruangan yang tersedia juga sangat memadai untuk melakukan proses belajar, selain itu fasilitas yang disediakan di sekolah cukup memadai akan tetapi jika kita menerapkan metode yang berbasis pada siswa kita memerlukan media dan alat bantu lainnya sedangkan di sekolah tersebut belum tersedia. Maka dari itu metode ceramah lah metode yang paling efektif untuk diterapkan".

Untuk mengetahui alasan ini penulis juga mewawancarai bapak Kepala Sekolah yang bernama bapak Purwadi S.Pd (wawancara tanggal 18 November 202) mengatakan bahwa: 
"Ya karna metode ceramah ini metode yang efektif untuk dilaksankan dalam proses pembelajaran, di sekolah ini tidak hanya menggunakan metode ceramah saja. Akan tetapi terkadang guru juga menggunakan metode diskusi, tanya jawab, dan penugasan. Jika dilihat dari proses belajar, siswa merasa senang. setelah itu jika terdapat problem ketika menggunakan metode ceramah padahal di Kurikulum 13 dituntut untuk menggunakan metode yang berbasis pada siswa, bapak akan memberi teguran atau peringatan untuk guru agar dalam proses pembelajaran penggunaan metode dikombinasikan dengan metode yang sesuai pada kurikulum 13 dan tidak hanya terfokus pada metode ceramah saja".

Penulis melihat bahwa guru menerapkan metode ceramah yang dikombinasikan dengan metode diskusi, tanya jawab dan penugasan. Ketika guru sedang mengajar penulis melihat metode ceramah itu sangat efektif untuk dilaksnakann. Fasilitas yang disediakan oleh sekolah juga cukup memadai, seperti halnya ruang kelas yang bersih, nyaman, dan alat bantu untuk melaksanakan proses belajar yaitu papan tulis, spidol dan buku panduan. Serta siswa juga merasa senang selama proses belajar dan perilaku siswa juga baik saat diterapkan metode ceramah.

Selanjutnya penulis juga mewancarai seorang siswi kelas IV SD N 161/II Bukit Sari yang bernama Lina Ardhita pada tanggal 23 November 2021 siswa mengatakan bahwa:

"Ketika belajar pendidikan agama Islam menggunakan metode ceramah saya tidak merasa kesulitan, karena ketika ibu menjelaskan saya mendengarkan dengan baik dan mudah memahami materi... Jadi saya lebih senang menggunakan metode ceramah dari pada metode lainya karena metode ceramah ini metode yang mudah dilaksanakan dan tidak perlu membuat kelompok dengan teman-teman".

Berdasarkan hasil observasi dan wawancara yang penulis lakukan maka dapat hasil sebagai berikut:

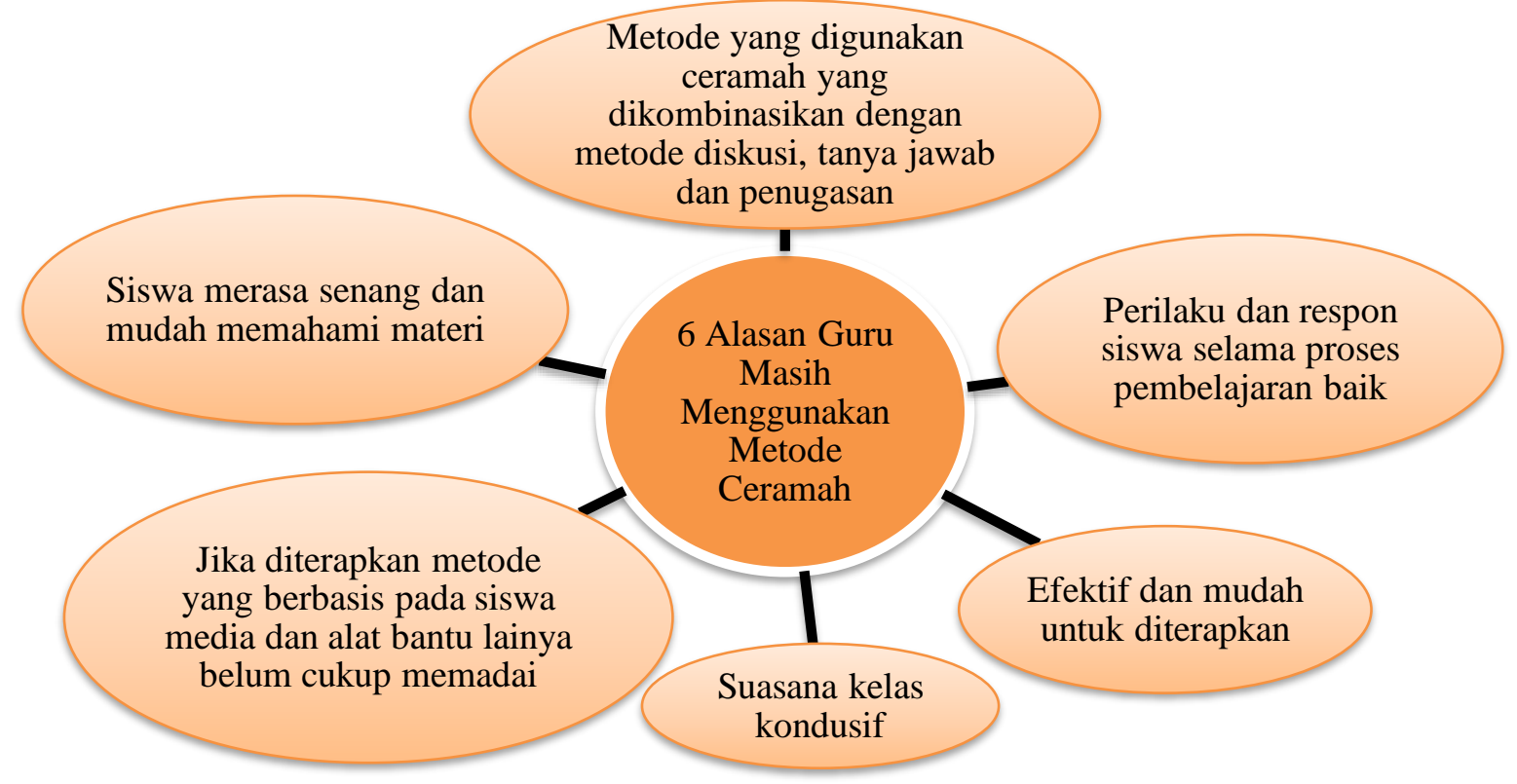

Gambar 6. Alasan Guru Tetap Menggunakan Metode Ceramah

Dari temuan penelitian di atas, mengungkapkan alasan guru PAI masih menggunakan metode ceramah adalah: 
Tri Sumarsih dan Wirdati: Enam Alasan Guru Menggunakan Metode Ceramah...

1) Metode yang digunakan ceramah yang dikombinasikan dengan metode diskusi, tanya jawab dan penugasan

Menurut Subianto (2016) penggunaan metode ceramah yang dikombinasikan dengan metode pembelajaran lainya seperti metode tanya jawab, diskusi, metode pembiasaan, penugasan dan cerita dapat menjadikan proses belajar lebih efektif. Dalam pelaksanaan pembelajaran apabila menggunakan bahasa yang mudah dipahami oleh siswa maka proses belajar akan berjalan dengan baik, maka dari itu penggunaan bahasa yang jelas akan memudahkan siswa untuk memahami materi yang dijelaskan oleh guru.

Maka dari itu penggunaan metode dalam proses pembelajaran sangatlah berpengaruh, karena terdapat beberapa alasan bahwa metode ceramah ini lebih efektif ketika diterapkan untuk sekolah yang dimana proses belajarnya masih murni menggunakan metode ceramah saja tanpa ada kombinasi metode lainya. Akan tetapi untuk keberadaan hari ini yang pelaksanaan proses belajarnya dilakukan secara daring dan kita bisa mendapatkan info dari mana saja, maka metode ceramah ini perlu dikombinasikan dengan metode lainya. Hal ini sesui dengan pelaksanaan di SD Negeri 161/II Bukit Sari dimana proses pembelajaran menggunakan metode ceramah yang sudah dikombinasikan dengan metode lainnya, meskipun sekolah tersebut belum melaksanakn metode yang berbasis pada siswa seperti halnya dalam Kurikulum 13.

Dalam proses belajar di SD Negeri 161/II Bukit masih cenderung menggunakan metode ceramah untuk materi-materi pokok. Akan tetapi terkadang guru juga menerapkan metode diskusi untuk materi tertentu pula agar proses pembelajrannya tidak menggunakan metode ceramah saja. Penggunaan metode ceramah yang diselingi dengan metode lain saat proses belajar saat berpengaruh untuk siswa, karena siswa akan merasa senang dan tidak bosan.

\section{2) Perilaku dan respon siswa selama proses pembelajaran baik}

Perilaku adalah suatu tindakan yang dapat diamati dam mempunyai frekuensi spesifik dan suatu tujuan yang disadari atau tidak (Wawan.2011). Apabila prilaku dan respon siswa baik maka bisa dikatakan guru berhasil dalam melakukan proses belajar serta guru tersebut juga bisa menerapkan metode yang digunakan. Dalam suatu pembelajaran prilaku dan respon siswa sangat lah berpengaruh karena jika respon siswa tidak baik kemungkinan besar proses belajar belum terlaksana dengan baik. Maka dari itu dalam proses pembelajaran guru juga harus memperhatikan pemahaman dan prilaku siswa, begitula di SD Negeri 161/II Bukit Sari dimana dalam proses pembelajaran guru tersebut tidak hanya fokus pada satu tujuan akan tetapi selam proses belajar guru juga memperhatikan siswa agar guru dapat mengetahui bagaimana respon siswa terhadap materi yang dijelaskan. Karena jika respon dan prilaku siswa selama proses belajar baik maka dalam pemilihan metode bisa dikatakan tepat dan baik untuk diterapkan.

\section{3) Efektif dan mudah untuk diterapkan}

Efektif adalah tercapainya suatu tujuan yang direncanaka dengan mengunakan sumber-sumber tertentu yang sudah disiapkan untuk melakukan kegiatan tertentu (Handoko.2000). Efektivitas merupakan usaha untuk mencapai sasaran yang telah diterapkan sesuai dengan kebutuhan, rencana, dengan menggunakan data, sarana, maupun waktu yang tersedia untuk memperoleh hasil yang maksimal baik secara 
kuantitatif maupun kualitatif. Efektivitas adalah situasi dimana dalam memilih tujuan yang tepat dan sarana untuk mencapai tujuan yang telah ditepakan dala pembelajaran (Ekasari.2020:20).

Keefektifan suatu pembelajaran dapat dilihat dari penggunaan metode dan cara guru menerapkan metode tersbut. Seperti yang telah penulis lihat bahwa dalam penggunaan metode di SD Negeri 161/II Bukit Sari guru cenderung menggunakan metode ceramah yang dikombinasikan dengan metode lainya, hal itu dilakukan karena di SD Negeri 161/II Bukit Sari karena metode tersebut efektifdan dapat diterapkan dengan baik. Meskipun di era saat ini dituntut untuk menggunakan metode yang berbasis pada siswa seperti hanya dalam Kurikulum 13. Keefektifan suatu pembelajaran dilihat dari bagaimana respond an hasil belajar siswa serta bagaimana siswa tersebut memahami materi yang diajarkan oleh guru

\section{4) Suasana kelas kondusif}

Menurut KBBI kondusif adalah suatu kondisi yang tenang dan tidak kacau balau, serta mendukung untuk terjadinya suatu aktivitas atau tujuan tertentu. Dalam proses pembelajaran kelas yang kondusif sangat penting karena dapat dapat memudahkan untuk pencapian suatu tujuan pembelajaran. Untuk menciptakan suasana belajar yang kondusif biasanya kita perlu memerhatikan dan memahami karakter siswa yang berbeda-beda tingkah lakunya serta penyusunan ruang kelas saat proses belajar berlansung.

Sesuai dengan penjelasan di atas penulis melihat bahwa pelaksanaan proses belajar di SD Negeri 161/II Bukit Sari suasana saat belajar sudak kondusif karena dalam penataan tempat untuk belajar guru menyusunya dengan rapi seperti halnya dalam posisi tempat duduk, ruang kelas yang nyaman dan kebersihan kelas. Selain itu guru juga dapat menguasai kelas dengan baik sehinga siswa merasa diperhatiakn oleh guru saat proses belajar berlanggusng, serta menjadikan proses belajar berjalan dengan baik dan siswa merasa senang dan nyaman. Dalam proses pembelajaran kenyamanan dan kesenangan siswa sangatlah berpengaruh terhadap proses belajar, jika siswa tidak merasa nyaman dan senang maka suasana kelas tersebut tidak akan kondusif. Maka dari itu dalam proses pembelajaran guru juga harus bisa mengusai kelas dan memahami siswa serta lingkungan kelas tersebut.

5) Jika diterapkan metode yang berbasis pada siswa media dan alat bantu lainya

belum cukup memadai

Dalam proses pembelajaran kelengkapan fasilitas sangatlah diperlukan untuk mendapatkan suatu informasi yang cukup agar metode tersebut dapat berjalan dengan baik dan sesuai dengan apa yang direncanakan. Selain itu dalam proses pembelajaran memerlukan sarana pendukung yang memadai seperti laptop, proyektor, jaringan internet, jaringan wifi, dan sarana prasarana lainnya. Karena dalam proses pembelajaran ketersedian fasilitas yang memadai perlu dalam penggunaan metode tertentu seperti project based learning (pembelajaran berbasis proyek), problem based learning (pembelajaran berbasis masalah), diccovery learning (pembelajaran berbasis penemuan), inquiri dan lainnya (Yusuf, 2018:268).

Dalam hal itu kelengkapan fasilitas yang terdapat di SD Negeri 161/II Bukit Sari sudah memadai akan tetapi jika diterapkan metode yang berbasis pada siswa sesuai yang ada di Kurikulum 13 maka fasilitas yang tersedia belum sepenuhnya memadai seperti halnya media. Karena dalam menggunaka motode yang berbasis pada siswa sangat memerlukan media dan alat bantu lainya untuk menjadikan pembelajaran itu 
Tri Sumarsih dan Wirdati: Enam Alasan Guru Menggunakan Metode Ceramah...

lebih efektif. Sehingga mampu menumbuh kembangkan dan mendorong peserta didik untuk menjalankan proses pembelajaran yang lebih baik. Maka dari itu dalam penggunaan metode pembelajaran di SD Negeri 161/II Bukit Sari masih menggunakan metode ceramah yang di dikombinasikan dengan metode diskusi, tanya jawab dan penugasan, karena metode tersebut tidak memerlukan fasilitas yang banyak.

6) Siswa merasa senang dan mudah memahami materi

Ketika penggunaan metode yang tepat maka hasil belajar pun juga akan baik. Begitu juga dengan siswa yang dengan mudah mereka memahami materi saat proses belajar berlangsung, serta siswa juga akan merasa senang karena dia memiliki respon sangat baik. Jika selama proses belajar siswa merasa senang maka bisa dikatan penggunaan metode dalam suatu pembelajaran itu berhasil dan guru juga dapat menerapkannya dengan baik. Begitu pula di SD Negeri 161/II Bukit Sari siswa merasa senang karena ketika proses belajar berlangsung siswa bisa secara langsung mendengarkan penjelasan dari guru dan ketika siswa kurang memahami materi siswa juga bisa langsung bertanya ke guru. Selain itu siswa juga mudah memahami materi yang dijelaskan oleh guru.

\section{Simpulan}

Ada enam alasan guru masih menggunakan metode ceramah yaitu metode yang digunakan di sekolah adalah metode ceramah yang dikombinasikan dengan metode diskusi, tanya jawab dan penugasan. Metode ceramah ini metode yang efektif dan mudah untuk diterapkan, kondisi kelas selama proses belajar berlangsung kondusif, fasilitas yang disediakan di sekolah cukup memadai akan tetapi jika di terapkan metode yang berbasis pada siswa belum bisa berjalan dengan b aik karena media dan alat bantu lainya belum cukup memadai, siswa merasa senang dan mudah memahami materi dan perilaku dan respon siswa selama proses pembelajaran baik.

\section{Referensi}

Asfiati. 2020 . Pembelajaran Pendidikan Agama Islam. Jakarta: Kencana.

Delina, Fitra. 2020. Perencanaan Pembelajaran Geografi. Jakarta: Haura Fitrah, M. dan L. 2017. Metodologi penelitian Penelitian Kualitatif, Tindakan

Kelas \& Studi Kasus. Jawa Barat : CV Jejak.

Hanafi dkk. 2018. Ilmu Pendidikan Islam. CV Budi Utama: Yogyakarta.

Januarharyono, Yudhaswara. 2019. Peran Pemuda di Era Globalisasi. Jurnal Ilmiah Magister Ilmu Administrasi, 13(1).

Kamus Besar Bahasa Indonesia (KBBI)

Maisaroh Siti. 2013. Peranan Metode Pembelajaran Terhadap Minat Dan Prestasi

Belajar Pendidikan Agama Islam. Jurnal Kependidikan, 1(1), 155.

Mudlofir \& Rusydiyah. 2017. Desain Pembelajaran Inovatif Dari Teori Ke Praktik. PT

Rajagrafindo Persada :Jawa Barat. 33

Nuryanti, Tuti \&Charifudin. 2020. Pendidikan Milenial di Era Globalisasi. Jurnal

Pendidikan, 1(3), 361.

Peraturan Pemerintah Republik Indonesia (PPRI) Nomor 32 Tahun 2013 Tentang

Tujuan Pendidikan Agama Islam.

PP No. 103 Tahun 2014 Tentang Kurikulum 2013

Rusiadi. 2020. Varias Metode Dan Media Pembelajaran Guru Pendidikan Agama 
Islam. Jurnal Alwatzikhoebillah, 6(2).

Sagala, S. 2013. Etika \& Moralitas Pendidikan. Jakarta : Kencana.

Samrin. 2015. Pendidikan Agama Islam Dalam Sistem Pendidikan Nasional Di Indonesia. Jurnal Al-Ta'dib, 8(1), 105-106.

Sanjaya, W. 2016. Strategi Pembelajaran Berorientasi Standar Proses Pendidikan. Jakarta : Kencana.

Suprihatiningsih. 2016. Perspektif Manajemen Pembelajaran Program 34 Keteramplan. CV Budi Utama : Yogyakarta.

T. Hani Handoko. 2000. Organisasi Perusahaan Teori, Struktur, Dan Perilaku. Yogyakarta: BPFE

A. Wawan \& Dewi M. 2011. Teori Dan Pengukuran Pengetahuan, Sikap, Dan Perilaku Manusia. Cetakan II. Yogyakarta : Nuha Medika.

Yusuf, Wiwin Fahrudhin. 2018. Implementasi Kurikulum 2013 (K-13) Pada Mata Pelajaran Pendidikan Agama Islam Sekolah Dasar (SD). Jurnal Pendidikan Agama Islam, 3(2),263. 